\title{
A Review on the Reproductive Dysfunction in Farmed Finfish
}

\author{
S. Selvaraj ${ }^{1 *}$, P. Chidambaram ${ }^{1}$, V. Ezhilarasi ${ }^{1}$, P. Pavin Kumar ${ }^{2}$, \\ T. L. S. Samuel Moses ${ }^{1}$, Cheryl Antony ${ }^{1}$ and B. Ahilan ${ }^{1}$ \\ ${ }^{1}$ Department of Aquaculture, Tamil Nadu Dr. J. Jayalalithaa Fisheries University, Dr. M.G.R. Fisheries \\ College and Research Institute, Ponneri, Tamil Nadu 601 204, India. \\ ${ }^{2}$ Department of Fisheries Resource Management, Tamil Nadu Dr. J. Jayalalithaa Fisheries University, \\ Dr. M.G.R. Fisheries College and Research Institute, Ponneri, Tamil Nadu 601 204, India.
}

Authors' contributions

This work was carried out in collaboration among all authors. All authors read and approved the final manuscript.

Article Information

DOI: $10.9734 / A R R B / 2021 / v 36 i 1030437$

Editor(s):

(1) Dr. Md. Torequl Islam, Federal University of Piaui, Brazil.

Reviewers:

(1) Habib UI Hassan, University of Karachi, Pakistan. (2) Gehan Hamdy Soliman, Menoufia University, Egypt.

Complete Peer review History: https://www.sdiarticle4.com/review-history/75461

Review Article

Received 04 August 2021

Accepted 13 October 2021

Published 18 October 2021

\begin{abstract}
Globally, fish production in the wild is decreasing, and different aquaculture systems are presently being used for broodstock development in the captivity. Seasonally, broodstock raised in captivity exhibit different form of reproductive dysfunction at the level of the brain-pituitary-gonad (BPG) axis. Primarily, vitellogenic completion and final oocyte maturation are inhibited in females, and males fail to spermiate spontaneously in the captivity. Reproductive dysfunctions are also observed during sexual differentiation, pubertal onset and sex conversion periods in teleosts. To overcome these problems, different hormonal preparations, primarily gonadotropin-releasing hormones $(\mathrm{GnRH})$ are used. In recent years, kisspeptins have been shown to be potent in inducing gonadal growth and maturation in teleost fish. Understanding the form of reproductive dysfunction is important in formulating suitable hormonal preparations for inducing gametogenesis. The paper reviews the problem of reproductive dysfunction and their possible reason for formulating different hormonal preparations.
\end{abstract}


Keywords: Reproductive dysfunction; BPG axis; GnRH analogue; gametogenesis.

\section{INTRODUCTION}

Fish maintained in different aquaculture system fail to experience natural environmental conditions, and result in the failure of reproductive system to complete normal gametogenic cycle in the captivity. Cultured adult fish exhibit different form of reproductive dysfunction, observed during seasonal reproductive cycle [1-9]. In gonochortistic female teleost fish, the two major problems encountered are failure to initiate and complete the vitellogenesis, and the other is failure to undergo final oocyte maturation and ovulation, after completion of vitellogenesis in the captivity. In cultured males, spermiation is the major problem encountered; however, problem in the completion of spermatogenesis have been reported in few cultured freshwater and marine species $[4,6]$. A shift in the sexual differentiation and pubertal onset timing periods has been reported in few farmed finfish [10]. Particularly, pubertal onset is delayed in number of large teleost species including marine scombrids which take several years to initiate first reproductive cycle in the captivity [11-14]. Primarily, low activities of different elements of reproductive brain-pituitary-gonad (BPG) axis including kisspeptin, gonadotropin-releasing homone and sex steroid have been attributed primarily to the reproductive dysfunction in captivity.

\section{REPRODUCTIVE BRAIN-PITUITARY- GONAD (BPG) AXIS}

BPG axis is a reproductive axis involved in the regulation of fish gametogenesis $[3,15,16,17-$ 21]. It is well known that brain gonadotropinreleasing hormone $(\mathrm{GnRH})$ play a major role in the control of pituitary gonadotropins, follicle stimulating hormone (FSH) and luteinizing hormone (LH). These pituitary GtHs in turn regulate the production of sex steroids driving different stages of gametogensis [22]. As teleost fish express multiple GnRH forms in the brain, more than one form suggested to be involved in the stimulation of pituitary gonadotropins suggesting their complexity in modulating gametogenesis [3].

Particularly, in late evolved fish, such as Perciformes, Atheriniformes and Pleuronectiformes expressing three GnRh forms, GnRh1 form has been shown to be predominantly involved in the control of pituitary
Fsh and Lh release [3,23]. In cyprinids and salmonids expressing two GnRh forms, GnRh3 form was found to be controlling the pituitary Fsh and Lh release [8,24]. GnRH acts at a highest level of the BPG axis and has advantage than the use of pituitary gonadotropin preparations including crude pituitary extract and HCG. Chemically synthesized $\mathrm{GnRH}$ eliminates the risk of the transmission of disease, and high degree of interspecies similarity of $\mathrm{GnRH}$ decapeptides allow single preparation to be used for more than one fish species [25]. The differences in multiple $\mathrm{GnRH}$ forms need to be considered while selecting inducing agents based on $\mathrm{GnRH}$ in finfish breeding. In recent years, several upstream regulators have been demonstrated to influence $\mathrm{GnRH}$ systems in fish [9,26-28].

\section{REPRODUCTIVE DYSFUNCTION IN FARMED FINFISH}

Cultured eel, mullet and jack mackerel fail to complete vitellogenesis in the captivity, based on the observation of repeated injection of inducing agents like human chorionic gonadotropin (hCG) and $\mathrm{GnRH}$ failing to induce positive influence $[8,29]$. Interestingly, few studies have indicated low expression of brain gnrh1, and pituitary fsh and $I h$ in cultured fish, in comparison to wild fish of similar reproductive stages [30-33]. Also, studies have confirmed low level of circulating Estradiol-17 $\beta$ in the peripheral circulation and low expression of aromatase [3,34]. These low expressions of different elements of BPG axis result in higher rate of ovarian atresia.

In marine scombrids including chub mackerel, female fish fail to complete final oocyte maturation in captivity. In these species, studies have confirmed low level of pituitary $\mathrm{GnRH}$ and LH $[32,33,35,36]$. Also, circulating levels of maturation inducing hormone, $17 \alpha, 20 \beta$ -

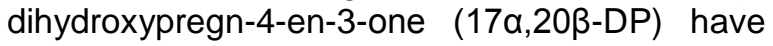
been low in captive fish when compared to wild fish of the same reproductive stage. Similar reasons have been attributed to male fish failing to spermiate in captivity. Overall, it is clear that captive stress and absence of natural environment results in the reduced activity of BPG axis [3,5,6,37-39].

In gonochoristic male fish, spermiation is the major problem encountered. However, problem at the level of spermatogenesis have been reported, and few freshwater species fail to 
undergo spermatogenesis in captivity. In addition, few species of captive females and males take longer duration to undergo gonadal growth and maturation. To overcome these problems, several hormonal preparations have been used and found to show prominent results $[3,8]$. Gonadal steroids play major roles in controlling the synthesis and release of FSH and $\mathrm{LH}$, and both positive and negative feedback effects of androgen and estrogen have been demonstrated in teleosts [11,22,40-44]. In captivity, operation of positive and negative back loop affected due to onset of ovarian follicular atresia and apoptosis, resulting in low level of sex steroids.

Due to lack of suitable environmental conditions and limited breeding tank space, significant rise in the hormonal levels of brain $\mathrm{GnRH}$, pituitary GtHs and sex steroids are not observed [5,6,45]. This is observed in several species including Indian major carps, Chinese carps and Indian catfish which fail to exhibit spawning in the captivity [46-51]. Crude pituitary extracts containing gonadotropins and purified fish gonadotropins were used for induced breeding in salmonids, cyprinids, cichlids and later attempted in several finfish [1,2,52-60]. In recent years, slow releasing devices like osmotic pumps are used for administering pituitary extract particularly in species which fail to initiate vitellogenesis in captivity. Japanese eel (Anguilla japonica), which fail to initiate vitellogenesis in captivity, implantation of a single salmon pituitary extract loaded osmotic pump (1.5-4 mg/day/fish) significantly stimulates vitellogenesis, and subsequent implantation of the same osmotic pump yield fully-grown female eels [29]. Similar strategy can be applied for species exhibiting severe reproductive dysfunction in captivity [24].

Difficulty in obtaining the purified and concentrated form of fish gonadotropins, other inducing agents like $\mathrm{GnRH}$ analogues are presently used widely in the aquaculture. Particularly, synthetic $\mathrm{GnRH}$ based analogues like Ovaprim, Ovatide and WOVA-FH and several other products designed based on $\mathrm{GnRH}$ based analogue are presently used for induced breeding of finfish in India [50,61]. Particularly, in cyprinids showing strong dopaminergic inhibition, dopamine receptor antagonists like domperidone and pimozide are incorporated along with $\mathrm{LHRH}$ or $\mathrm{GnRH}$ preparations [54,62]. Like pituitary extract, few studies have indicated the potency of brain extract to induce pituitary gonadotropins under in-vitro and in-vivo conditions [23,63].
Multiple spawning in Chinese carps has been achieved through administration of multiple hormones. Two injections of luteinizing hormone releasing hormone analogue ( $\mathrm{LHRH}-\mathrm{a})$, human chorionic gonadotropin (HCG), carp pituitary (PG) or a combination of two of these induces multiple spawning in Chinese carps [48]. Additionally, multiple spawning is affected in captive maintained females and males. This is mainly due to the sustained release of brain $\mathrm{GnRH}$ and pituitary LH in subsequent progression of different stages of gametogenesis. In few species, decrease in the circulating sex steroids has been demonstrated, resulting in ovarian follicular atresia and failing to spermiate in females and males, respectively. In Indian catfishes, administration of oxytocin after $\mathrm{GnRHa}$ injection induces voluntary captive spawning, suggesting possibility in application of similar methods for obtaining higher quality eggs in Indian major carps and Chinese carps [63,64]. In recent years, development of ELISA based systems for quantifying the circulating $\mathrm{FSH}$ and LH level in fish blood have improved our understating on their involvement in different stages of gametogenesis, and hormone dose requirement for induced breeding in aquaculture.

\section{GnRH ANALOGUES IN INDUCED BREEDING}

The functional part of $\mathrm{GnRH}$ protein is decapeptide that is processed from the precursor by removal of the signal peptide and cleavage at the dibasic amine acid to separate $\mathrm{GnRH}$ associated peptide (GAP) region [3,24]. NCBI GenBank accession nos. of finfish expressing three and two $\mathrm{GnRH}$ forms in the brain are shown in Table 1 and Table 2, respectively. Amino acid sequences of multiple $\mathrm{GnRH}$ forms in finfish are presented in Table 3. Teleosts share the mammalian $\mathrm{GnRH}(\mathrm{mGnRH})$ form in the $\mathrm{GnRH1}$ group with other vertebrates $[65,66]$. However, different variant of $\mathrm{GnRH} 1$ form has been reported in seabream (Sparus aurata), medaka (Oryzias latipes), pejerrey (Odontesthes bonariensis), African catfish (Clarias gariepinus), herring (Clupea harengus pallasi), whitefish, (Coregonus clupeaformis), spotted catshark (Scyliorhinus canicula), dogfish (Squalus acanthias) and Sea lamprey, Petromyzon marinus [3,67] (Table 1).

Decapeptide $\mathrm{GnRH}$ analogues commonly used in finfish breeding are an analogue of mammalian $\mathrm{GnRH}$, called LHRHa and an analogue of salmon $\mathrm{GnRH}$, called sGnRHa 
[7,102]. GnRH analogues are primarily designed from the functional decapeptide region. Amino acid at position 6 (Glycine) is highly conserved in different fish species but suggested to be a target site for proteolytic digestion and thus, reducing the half-life of the peptide in circulation [103]. In these analogues, two modifications are performed. D-Amino acid that are mirror image forms of naturally occurring L-form, are substituted at $6^{\text {th }}$ position, making $\mathrm{GnRH}$ analogue more resistant to degradation and increased half life in the peripheral circulation [104]. Also, both analogues lack $10^{\text {th }}$ amino acid, and instead end with an ethylamide $\left(\mathrm{NH}-\mathrm{CH}_{2}-\right.$ $\mathrm{CH}_{3}$; abbreviated as NEt). This modification at $10^{\text {th }}$ position increases binding affinity towards its cognate receptor. The primary structure for mammalian $\mathrm{GnRH}$ is Glu-His-Trp-Ser-Tyr-GlyLeu-Arg-Pro-Gly- $\mathrm{NH}_{2}$ and the corresponding analogue is Glu-His-Trp-Ser-Tyr-D-Ala-Leu-ArgPro- $\mathrm{NH}-\mathrm{CH}_{2}-\mathrm{CH}_{3}$. Likewise for salmon $\mathrm{GnRH}$ is Glu-His-Trp-Ser-Tyr-Gly-Trp-Leu-Pro-Gly- $\mathrm{NH}_{2}$ and the corresponding analogue is Glu-His-TrpSer-Tyr-D-Arg-Trp-Leu-Pro-NH- $\mathrm{CH}_{2}-\mathrm{CH}_{3}$ [53,102]. Amino acid sequences of $\mathrm{GnRH}$ analogues used in induced breeding of finfish are presented in Table 4. GnRH decapeptide and its synthetic analogues are shown to stimulate gonadotropin secretion in teleosts. However, in many cyprinids gonadotropin releasing inhibiting factor (GRIF's) inhibits the effect of GnRH decapeptide on gonadotropin $(\mathrm{GtH})$ release. This inhibitory effect is prevented by inclusion of dopamine receptor antagonists such as domperidone, pimozide, metoclopramide, or reserpine in the $\mathrm{GnRH}$ decapeptide [53,54]. $\mathrm{GnRH}$ analogues are sold in many brand names in different countries, with modifications in $6^{\text {th }}$ and $10^{\text {th }}$ amino acid positions. These analogues are administered using different ways: intramuscular, intravenous, intraperitoneal and intracranial.

Several studies have indicated use of different forms of $\mathrm{GnRH}$ decapeptide in inducing $\mathrm{GtH}$ mRNAs under in-vitro conditions including differential response of administered $\mathrm{GnRH}$ at different stages of gametogenesis $[30,103]$. Lumayno et al. [39] demonstrated that all three native forms of $\mathrm{GnRH}$ including a mammalian $\mathrm{GnRH}$ analogue stimulate luteinizing hormone from cultured pituitary cells of chub mackerel under invitro condition, suggesting the potency of native multiple $\mathrm{GnRH}$ forms in induced breeding. Several studies have demonstrated that $\mathrm{GnRH} 2$ (cGnRH-II form) has a higher binding affinity compared to other $\mathrm{GnRH}$ forms mainly due to the preconfigured $\beta$-II' conformation [104].
GnRHa releasing-systems are successfully used to stimulate gonadal development, maturation and spawning of the gametes in several finfish species $[4,61,105,106]$. During the last two decades, various $\mathrm{GnRHa}$ administration methods were evaluated in aquacultured finfish $[4,24]$. For sustained release of pituitary gonadotropin in stimulating gametogenesis in multiple spawning finfish, recent developments resulted in the $\mathrm{GnRHa}$ incorporation in a polymeric controlled releasing system, which allow releasing of hormone from controlled devices like osmotic pumps for a period or days or weeks or months $[4,26,106,107]$. The compounds commonly used as slow releasing medium are cholesterol and cellulose, lactic acid and glycolic acid, or copolymers of dimer fatty acid and sebasic acid, or acetate of ethylene and vinyl (EVAc). Depending on the type of reproductive dysfunction and species size, body shape and other biological features of the species, slow-releasing medium and -devices can be selected for induced breeding.

\section{PUBERTAL ONSET IN FARMED FINFISH}

Puberty in fish is the developmental period during which an individual becomes capable of reproducing sexually for the first time, and associated with an appearance of meiotic germ cells in the testis and ovary [108-110]. Several reasons have been hypothesized for delay in the onset of puberty in fish [10]. One major reason is the delay in the complete maturation of immuneeuroendocrine circuits and networks. Unlike mammals, fish lack bone marrow and lymph nodes; instead, the spleen and head kidney are sites for the interaction of immune system with antigens and harbor the antibody producing lymphocytes. The thymus is a primary lymphoid organ acting as a centre of T-lymphocyte maturation and it is possible that delay in the complete maturation of this centre can result in delay in pubertal onset in fish [111]. Members of the activin/inhibin subfamily have been found to play a major role in T cell homeostasis. Follistatin is a single chain protein with biological activities similar to those of inhibin, but it structurally unrelated to activin and inhibin. All the above three proteins are shown to regulate pituitary FSH secretion without significant effects on luteinizing hormone. Activin stimulates, whereas inhibin and follistatin suppress FSH secretion. It is possible that delay in the activation of the above system may result in the delayed progression of gametogenesis due to low activity 
of $\mathrm{FSH}$. It is well demonstrated that an increase in FSH level is necessary for progression of early gametogenesis [112]. In recent years, kisspeptin has been shown to be involved in the activation of reproductive BPG axis with evidences in few fish indicating that $\mathrm{GnRH}$ neurons express kisspeptin receptors to influence other downstream regulators $[13,17,113]$. Interestingly, in fish showing positive influence of kisspeptin on pubertal onset, emerging studies indicate that leptin directly influences gonadotropin secretion as leptin transmits information about energy stored in the peripheral tissues like adipose tissue and liver to the reproductive axis [114-
115]. Additionally, in-vivo administration of functional kisspeptin peptides induces spermatogenesis and oogenesis in immature fish [24]. Maintenance of constant temperature in different aquaculture systems induce early pubertal onset in farmed finfish [116,117]. Recent studies also indicate peripheral signals like leptin produced in liver and adipose tissues are involved in the control of pubertal onset in fish $[13,28,115]$. In migratory salmonids, salinity and photoperiod modulate pubertal onset [118]. In recent years, surrogate broodstock technology has been used to produce donor-derived gametes in surrogates $[119,120]$.

Table 1. GenBank accession nos. of finfish expressing three GnRH forms

\begin{tabular}{|c|c|c|c|c|}
\hline \multirow[t]{2}{*}{ Fish } & \multicolumn{3}{|c|}{ GenBank Accession Nos. } & \multirow[t]{2}{*}{ References } \\
\hline & gnrh1 & gnrh2 & gnrh3 & \\
\hline $\begin{array}{l}\text { Gilthead seabream, } \\
\text { Sparus aurata }\end{array}$ & U30320 & U30325 & U30311 & [68] \\
\hline $\begin{array}{l}\text { African cichlid fish, Haplochromis } \\
\text { burtoni }\end{array}$ & AF076963 & AF076962 & AF076961 & [69] \\
\hline $\begin{array}{l}\text { Medaka, } \\
\text { Oryzias latipes }\end{array}$ & $\begin{array}{l}\text { NP_0010981 } \\
69\end{array}$ & NC_019863 & AB041335 & {$[70,71]$} \\
\hline $\begin{array}{l}\text { Sea lamprey, } \\
\text { Petromyzon marinus }\end{array}$ & AF14448.1 & $\begin{array}{l}\text { AF144481, } \\
\text { DQ457017 }\end{array}$ & AY052628 & {$[72,73]$} \\
\hline $\begin{array}{l}\text { European sea bass, } \\
\text { Dicentrarchus labrax }\end{array}$ & AF224279 & AF224281 & AF224280 & {$[74,75]$} \\
\hline $\begin{array}{l}\text { Barfin flounder, } \\
\text { Verasper moseri }\end{array}$ & AB066360 & AB066359 & AB066358 & [76] \\
\hline $\begin{array}{l}\text { Atlantic croaker, Micropogonias } \\
\text { undulatus }\end{array}$ & AY324668 & AY324669 & AY3246670 & [77] \\
\hline $\begin{array}{l}\text { Spotted green pufferfish, } \\
\text { Tetraodon nigroviridis }\end{array}$ & AB212811 & AB212812 & AB212814 & [78] \\
\hline $\begin{array}{l}\text { Nile tilapia, } \\
\text { Oreochromis niloticus }\end{array}$ & AB104861 & AB104862 & AB104863 & [79] \\
\hline $\begin{array}{l}\text { Cobia, } \\
\text { Rachycentron canadum }\end{array}$ & AY677175 & AY677174 & AY677173 & [80] \\
\hline $\begin{array}{l}\text { Pejerrey, } \\
\text { Odontesthes bonariensis }\end{array}$ & AY744689 & AY744687 & AY744688 & [81] \\
\hline $\begin{array}{l}\text { Black porgy, } \\
\text { Acanthopagrus schlegelii }\end{array}$ & EU099997 & EU099996 & EU117212 & [82] \\
\hline $\begin{array}{l}\text { Grey mullet, } \\
\text { Mugil cephalus }\end{array}$ & AY373450 & AY373451 & AY373449 & [83] \\
\hline $\begin{array}{l}\text { Goldlined seabream, } \\
\text { Rhabdosargus sarba }\end{array}$ & EF433770 & EF433771 & EF433772 & [84] \\
\hline $\begin{array}{l}\text { Grass puffer, } \\
\text { Takifugu niphobles }\end{array}$ & AB531127 & AB531128 & AB531129 & [85] \\
\hline $\begin{array}{l}\text { Bambooleaf wrasse, } \\
\text { Pseudolabrus sieboldi }\end{array}$ & KC896411 & KC896412 & KC896413 & {$[86,87]$} \\
\hline $\begin{array}{l}\text { Chub mackerel, } \\
\text { Scomber japonicus }\end{array}$ & HQ108193 & HQ108194 & HQ108195 & [35] \\
\hline $\begin{array}{l}\text { Japanese anchovy, Engraulis } \\
\text { japaonicus }\end{array}$ & JX406273 & JX406274 & JX406275 & [66] \\
\hline $\begin{array}{l}\text { Spotted catshark, Scyliorhinus } \\
\text { canicula }\end{array}$ & MH468810 & MH468811 & MH468812 & [87] \\
\hline
\end{tabular}


Table 2. GenBank accession nos. of finfish expressing two GnRH forms

\begin{tabular}{lllll}
\hline Fish & \multicolumn{3}{l}{ GenBank Accession Nos. } & References \\
\cline { 2 - 4 } & gnrh1 & gnrh2 & gnrh3 & \\
\hline $\begin{array}{l}\text { Goldfish, } \\
\text { Carassius auratus }\end{array}$ & - & U30386 & U30301 & [88-90] \\
\hline $\begin{array}{l}\text { Rainbow trout, } \\
\text { Oncorhynchus mykiss }\end{array}$ & - & AF125973 & X79710 & {$[91,92]$} \\
\hline $\begin{array}{l}\text { North African catfish, } \\
\text { Clarias gariepinus }\end{array}$ & X78049 & X78047 & - & {$[93]$} \\
\hline $\begin{array}{l}\text { Japanese Eel, } \\
\text { Anguilla japonica }\end{array}$ & AB026989 & AB026990 & - & [94] \\
\hline $\begin{array}{l}\text { Arowana, } \\
\text { Scleropages jardinii }\end{array}$ & - & AB047326 & AB047325 & [95] \\
\hline $\begin{array}{l}\text { Zebrafish, Danio rerio } \\
\begin{array}{l}\text { Common carp, } \\
\text { Cyprinus carpio }\end{array}\end{array}$ & - & NM_181439 & AJ304429 & {$[96,97]$} \\
\hline $\begin{array}{l}\text { chum salmon, } \\
\text { Oncorhynchus keta }\end{array}$ & - & AY246698 & AY189960 & {$[98,99]$} \\
\hline $\begin{array}{l}\text { Beluga, } \\
\text { Huso huso }\end{array}$ & EF534707 & EF534706 & - & {$[100]$} \\
\hline
\end{tabular}

Table 3. Amino acid sequences of naturally occurring multiple GnRH forms in finfish

\begin{tabular}{|c|c|c|c|c|c|c|c|c|c|c|}
\hline Position & 1 & 2 & 3 & 4 & 5 & 6 & 7 & 8 & 9 & 10 \\
\hline \multicolumn{11}{|l|}{ GnRH I forms } \\
\hline sbGnRH & pGlu & His & Trp & Ser & Tyr & Gly & Leu & Ser & Pro & $\begin{array}{l}\text { Gly- } \\
\mathrm{NH}_{2}\end{array}$ \\
\hline mGnRH & - & - & - & - & - & - & - & Arg & - & - \\
\hline pjGnRH & - & - & - & - & Phe & - & - & Ser & - & - \\
\hline $\mathrm{cfGnRH}$ & - & - & - & - & His & - & - & Asn & - & - \\
\hline hrGnRH & - & - & - & - & His & - & - & Ser & - & - \\
\hline wfGnRH & - & - & - & - & - & - & Met & Asn & - & - \\
\hline scGnRH & - & - & - & - & His & - & Trp & Arg & - & - \\
\hline dfGnRH & - & - & - & - & His & - & - & Leu & - & - \\
\hline $\mathrm{IGnRH}$ & - & - & Tyr & - & Leu & Glu & Trp & Lys & Pro & Gly-NH \\
\hline \multicolumn{11}{|l|}{ GnRH II forms } \\
\hline $\begin{array}{l}\text { cGnRH-II } \\
\text { (teleost) }\end{array}$ & pGlu & His & Trp & Ser & His & Gly & Trp & Tyr & Pro & $\begin{array}{l}\text { Gly- } \\
\mathrm{NH}_{2}\end{array}$ \\
\hline $\begin{array}{l}\text { cGnRH-II } \\
\text { (elasmobranch) }\end{array}$ & - & - & - & - & Phe & Asp & Tyr & Arg & - & - \\
\hline $\begin{array}{l}\text { IGnRH-II } \\
\text { (lamprey) }\end{array}$ & - & - & - & - & - & - & - & Phe & - & - \\
\hline \multicolumn{11}{|l|}{ GnRH III forms } \\
\hline $\begin{array}{l}\text { sGnRH } \\
\text { (teleost) }\end{array}$ & pGlu & His & Trp & Ser & Tyr & Gly & Trp & Leu & Pro & $\begin{array}{l}\text { Gly- } \\
\mathrm{NH}_{2}\end{array}$ \\
\hline $\begin{array}{l}\text { sGnRH } \\
\text { (elasmobranch) }\end{array}$ & - & - & - & - & Phe & Asp & - & - & - & - \\
\hline $\begin{array}{l}\text { IGnRH-III } \\
\text { (lamprey) }\end{array}$ & - & - & - & - & His & Asp & - & - & - & - \\
\hline
\end{tabular}


Table 4. Amino acid sequences of GnRH I and GnRH III analogues used in induced breeding of finfish

\begin{tabular}{|c|c|c|c|c|c|c|c|c|c|c|}
\hline Position & 1 & 2 & 3 & 4 & 5 & 6 & 7 & 8 & 9 & 10 \\
\hline \multicolumn{11}{|c|}{ GnRH I analogues } \\
\hline Mammalian & pGlu & His & Trp & Ser & Tyr & D-Ala & Leu & Arg & Pro & Net \\
\hline \multirow[t]{5}{*}{$\mathrm{GnRH}$} & - & - & - & - & - & D-Arg & Trp & Leu & - & Net \\
\hline & - & - & - & - & - & D-Tle & - & - & - & Net \\
\hline & - & - & - & - & - & D-Trp & - & - & - & Net \\
\hline & - & - & - & - & - & D-Nal (2) & - & - & - & $\begin{array}{l}\text { aza- } \\
\text { Gly }\end{array}$ \\
\hline & - & - & - & - & - & $\mathrm{D}-\mathrm{Ser}(\mathrm{t}-\mathrm{Bu})$ & - & - & - & Net \\
\hline \multicolumn{11}{|c|}{ GnRH III analogues } \\
\hline \multirow{4}{*}{$\begin{array}{l}\text { salmon } \\
\text { GnRH }\end{array}$} & pGlu & His & Trp & Ser & Tyr & D-Arg & Trp & Leu & Pro & Net \\
\hline & - & - & - & - & - & D-Lys & - & - & Pro & Net \\
\hline & - & - & - & - & - & Gly & - & - & Pro & Net \\
\hline & - & - & - & - & - & D-Lys & - & - & Pro & $\begin{array}{l}\text { Gly- } \\
\mathrm{NH}_{2}\end{array}$ \\
\hline
\end{tabular}

\section{SEX CHANGE CONVERSION CAPTIVE MAINTAINED FINFISH}

Sex change is widespread in teleosts and it is an ontogenetic event in some species; however, in others, it can be triggered by stimuli such as interaction with conspecifics [121,122]. Groupers and Asian seabass are naturally distributed in tropical and subtropical regions and they are aquacultued in many Asian countries including India [123-128]. Physiologically, they are known as protogynous and protandrous hermaphrodites with sex change from female to male and male to female, respectively. This kind of sexuality raises several problems in the broodstock management in fish hatchery and necessitates hormonal treatments for sex change in the hatchery [129131].

In several species, rise in the 11ketotestosetrone (11-KT) and 17ß-estradiol (E2) coincides with sex change to male and female, respectively [125-128]. Elevation in the serum glucocorticoid, cortisol has been demonstrated in gonochoristic fish species, including medaka, pejerrey, Japanese flounder that exhibit temperature induced masculinization. Also, cortisol is shown to be involved in the initiation of sex change in protogynous hermaphroditic fish. Sex change strategy in the groupers of the genus Epinephelus involves the size-advantage model with larger individuals undergoing a sex change after attaining a certain age and body size [122]. In blue spotted grouper, Epinephelus fario mature males through sex reversal by the oral administration of methyltestosterone at daily feeding doses of $0.5 \mathrm{mg}$ and $1.0 \mathrm{mg} \mathrm{MT} / \mathrm{kg}$ body weight for 5 months [129].

Physiologically, female to male sex change in the honeycomb grouper (Epinephelus merra) is associated with a drop in E2 levels followed by an increase in 11-KT levels $[122,125,126]$. Also, naturally occurring sex change is accompanied by significant increase in the size of androgen producing cells and androgen production by the gonads [123,124]. In several sex changing fish, levels of circulating 11-KT have been reported to increase with the progression of sex change. In captivity, steroidogenic pathways favoring production of androgen and estrogen in male (protogynous) and female (protandrous), respectively do not function effectively and result in delay in the sex change. Under aquaculture conditions, slow releasing $11-\mathrm{KT}$ implants (10 $\mathrm{ppm} / \mathrm{kg}$ body weight) were implanted into the body cavity; $100 \%$ masculinization was achieved on $75^{\text {th }}$ day [122]. In recent years, kisspeptin systems are shown to be involved during $17 \alpha-$ methyltestosterone-induced sex reversal in the grouper, likely to be through BPG axis $[110,130]$. Recent studies suggest that gonochorist teleost species are amenable to chemical-induced gonadal sex reversal even after sexual maturity [131].

\section{CONTROL OF SEXUAL DIFFERENTIATION IN CULTURED FISH}

Sexual differentiation of farmed finfish can be controlled using hormonal treatments, control in 
water quality parameters, and genetic manipulation [34,130-137]. Feminization in blue gill (Lepomis macrochirus) and blue crappie (Pomoxis nigromaculatus) are achieved by periodic immersions of fry in a $1 \mathrm{mg} / \mathrm{l}$ estradiol$17 \beta$ solution [138]. Also, feminized female tilapia are obtained by feeding fish diethylatilbesterol at $150 \mathrm{mg} / \mathrm{kg}$ feed. Similarly, feminization has been achieved in fish showing superior trait in females compared to males [139-141]. Several studies have demonstrated successful all male production of teleost fish using androgens $[134,136,137]$. In addition to androgens, enzyme inhibitors targeting steroidogenic pathways have been used. Rashid et al. (2007) ${ }^{[138]}$ indicated use of aromatase inhibitor, Fardrazole in the diet at a concentration between 500 and $1000 \mu \mathrm{g} / \mathrm{g}$ diet, which induces testicular development in fugu (Takifugu rubripes). Similar method has been used in variety of teleost fish $[139,140]$.

There is strong evidence that water temperature induces sex reversal in teleost fish. In Pejerrey (Odontesthes bonariensis), low temperature (15$\left.19^{\circ} \mathrm{C}\right)$ favours feminization [141,142]. Mozambique tilapia (Oreochromis mossambicus) reared at a high temperature $\left(37 \pm 0.5^{\circ} \mathrm{C}\right)$ for 50 days result in the sterilization of testes lacking spermatogenic germ cells. Nile tilapia (Oreochromis niloticus) juveniles prefer a masculinizing temperature of $36.5^{\circ} \mathrm{C}$ for inducing sex reversal to males [143]. Recently, it was demonstrated in yellow catfish (Tachysurus fulvidraco) that high temperature $\left(33.5^{\circ} \mathrm{C}\right)$ induces masculinization. Similar stratagies can be applied for manipulating sex and stimulating growth under aquacultured condition.

\section{CONCLUSION}

It is well demonstrated that different elements of BPG axis can be used as inducing agents in finfish aquaculture. In recent years, biotechnological tools have been used for production of recombinant proteins. Emerging studies indicate the possibility of using recombinant $\mathrm{FSH}$ and $\mathrm{LH}$ in inducing spermatogenesis in male eels, suggesting development of similar methods for other finfish. Also, it was demonstrated that recombinant gonadotropin-releasing hormone associated peptide can be used as an inducing agent for breeding in finfish. This strategy would work effectively in a number of fish species, in which repeated injection of $\mathrm{GnRH}$ fail to induce final oocyte maturation and spawning in captivity, including its application in manipulating the timing of pubertal onset and sex conversion. Interestingly, recent studies indicate the possibility of using kisspeptin peptide along with dopamine antagonists for inducing $\mathrm{LH}$ release in cyprinid fish and the response is dependent on the maturity stage of gonad. There is possibility that kisspeptin effect would be superior atleast in cyprinids and scombrids when compared to $\mathrm{GnRH}$ as it acts at higher level in the BPG axis and its effect on circulating steroid level would mediate positive feedback in the brain for sustained release of gonadotropins in fish exhibiting asynchronous ovarian development. Further studies in other freshwater and marine finfish are required to confirm the superior effect of kisspeptin peptides on induced spawning.

\section{COMPETING INTERESTS}

Authors have declared that no competing interests exist.

\section{REFERENCES}

1. Donaldson EM. Reproductive endocrinology of fishes. American Zoologist. 1973;13:909-927.

2. Lam TJ. Applications of endocrinology to fish culture. Canadian Journal of Aquatic and Fisheries Sciences. 1982;39:111-137. https://doi.org/10.1139/f82-013

3. Matsuyama M, Selvaraj S, Nyuji M, Ohga $\mathrm{H}$. Involvement of brain-pituitary-gonadal axis on regulation of reproductive cycle in female chub mackerel. In Sexual Plasticity and Gametogenesis in Fishes, 2013;251273, Nova Science Publishers Inc.

4. Mylonas CC, Zohar Y. Use of GnRHadelivery systems for the control of reproduction in fish. Reviews in Fish Biology and Fisheries 2001;10:463-491. https://doi.org/10.1023/A:1012279814708

5. Mylonas, CC., Zohar, Y. Promoting oocyte maturation, ovulation and spawning in farmed fish. In: Babin, P.J., Lubzens, E. (Eds.), The fish oocyte: from basic studies to biotechnological applications. Springer Press, Dordrecht, The Netherlands, 2007; 437-474.

6. Mylonas CC, Fostier A, Zanuy, S. Broodstock management and hormonal manipulations of reproduction. General and Comparative Endocrinology. 2010;165 (3):516-534. https://doi.org/10.1016/j.ygcen.2009.03.00 7 
7. Rainis S, Ballestrazzi R. The control of reproduction in finfish species through $\mathrm{GnRH}$ treatments. Italian Journal of Animal Sciences, 2005;4:345-353.

https://doi.org/10.4081/ijas.2005.345

8. Zohar, Y., Mylonas, C. Endocrine manipulations of spawning in cultured fish: from hormones to genes. Aquaculture 2001;197(1-4): 99-136.

https://doi.org/10.1016/S00448486(01)00584-1

9. Zohar Y. Fish reproductive biology Reflecting on five decades of fundamental and translational research. General and Comparative Endocrinology 2021; 300:113544. https://doi.org/10.1016/j.ygcen.2020.11354 4

10. Andersson E, Taranger GL, Wargelius A, Schulz, RW. Puberty in fish. In: Reference Module in Life Sciences - Encyclopedia of Reproduction (Second Edition). Elsevier, Amsterdam. 2008;426-429. encyclopediaof-reproduction/skinner/978-0-12-811899-3

11. Carrillo M, Zanuy S, Felip A, Bayarri MJ, Moles, G., Gomez, A. 2009. Hormonal and environmental control of puberty in perciform fish: the case of sea bass. Annals of the New York Academy of Sciences, 2008;1163:49-59.

https://doi.org/10.1111/j.1749

6632.2008.03645.x

12. Carrillo M, Espigares F, Felip A, Escobar $\mathrm{S}$, Moles $\mathrm{G}$, Rodriguez $\mathrm{R}$, Alvarado MV, Gomez A, Zanuy S. Updating control of puberty in male European sea bass: a holistic approach. General and Comparative Endocrinology. 2015;221:4253.

https://doi.org/10.1016/j.ygcen.2015.06.01 9

13. Ohga, $\mathrm{H}$, Adachi $\mathrm{H}$, Matsumori K, Kodama, K, Nyuji M, Selvaraj S, Kato K, Yamamoto, S, Yamaguchi A, Matsuyama M. mRNA levels of kisspeptins, kisspeptin receptors, and $\mathrm{GnRH} 1$ in the brain of chub mackerel during puberty. Comparative Biochemistry and Physiology Part A Molecular and Integrative Physiology. 2015;179:104-112. https://doi.org/10.1016/j.cbpa.2014.09.012

14. Ohga $H$, Adachi $H$, Kitano $H$, Yamaguchi A, Matsuyama M. Kiss1 hexadecapeptide directly regulates gonadotropin-releasing hormone in the scombroid fish, chub mackerel. Biology of Reproduction 2017;96:376-388. https://doi.org/10.1095/biolreprod.116.142 083

15. Goetz FW. Hormonal control of oocyte final maturation and ovulation in fishes. In: Fish Physiology, IXB (Hoar, W.S., Randall, D.J., Donaldson, E.M., Eds). Elsevier. 1983; 117-170.

16. Mañanós, E., Duncan, N., Mylonas, C. 2009. Reproduction and control of ovulation, spermiation and spawning in cultured fish. In. Methods in reproductive aquaculture. Eds. Cabrita, E., Robles, V., Herraez, CRC Press. 2009;572.

17. Ohga $H$, Fujinaga $M$, Selvaraj S, Kitano $H$, Nyuji M, Yamaguchi A, Matsuyama M. Identification, characterization, and expression profiles of two subtypes of kisspeptin receptors in a scombroid fish (chub mackerel). General and Comparative Endocrinology. 2013;193: 130-140.

https://doi.org/10.1016/j.ygcen.2013.07.01 6

18. Selvaraj S, Ohga H, Nyuji, M, Kitano, H., Nagano, N., Yamaguchi, A., Matsuyama, M. Effects of synthetic kisspeptin peptides and $\mathrm{GnRH}$ analogue on oocyte growth and circulating sex steroids in prepubertal female chub mackerel (Scomber japonicus). Aquaculture Research 2015;46:1866-1877. https://doi.org/10.1111/are.12342

19. Selvaraj, S., Kitano, H, Ohga H, Yamaguchi, A., Matsuyama, M. Expression changes of mRNAs encoding kisspeptins and their receptors and gonadotropinreleasing hormones during early development and gonadal sex differentiation periods in the brain of chub mackerel (Scomber japonicus). General and Comparative Endocrinology 2015; 222:20-32.

https://doi.org/10.1016/j.ygcen.2014.09.01 9

20. Tacon P, Ndiaye, P., Cauty, C., Le Mann, F., Jalabert, B. Relationships between the expression of maternal behavior and ovarian development in the mouthbrooding cichlid fish Oreochromis niloticus. Aquaculture 1996;146(3-4):261. https://doi.org/10.1016/S00448486(96)01389-0

21. Watanabe W, Wicklund, R., Olla, B., Head, W. Saltwater culture of Florida red tilapia and another saline-tolerant tilapias: A review. In: Tilapia Aquaculture in the Americas, Costa-Pierce, B. and Rockocy, 
E., Eds., Vol. I, The World Aquaculture Society, Louisiana, 1997;54

22. Yaron Z, Gur, G, Melamed P, Rosenfeld, H., Elizur, A., Levavi-Sivan, B. Regulation of fish gonadotorpins. International Review of Cytology 2003;225:131-185. https://doi.org/10.1016/S00747696(05)25004-0

23. Senthilkumaran B., Okuzawa, K., Gen, K., Ookura, T., Kagawa, H. Distribution and seasonal variations in levels of three native GnRHs in the brain and pituitary of perciform fish. Journal of Neuroendocriology. 1999;11:181-186. https://doi.org/10.1046/j.13652826.1999.00304.x

24. Selvaraj S, Kitano, H., Amano, M., Matsuyama, M. Dynamics of three GnRH forms in the multiple spawning perciform fish, chub mackerel (Scomber japonicus) and bambooleaf wrasse (Pseudolabrus sieboldi). In Gonadotropin-Releasing Hormone (GnRH): Production, Structure and Functions. Nova Science Publishers Inc. 2013; 29-54.

25. Nazari RM, Modanloo M, Ghomi MR, Ovissipor MR. Application of synthetic hormone $\mathrm{LHRH}-\mathrm{A}_{2}$ on the artificial propagation of Persian sturgeon Acipenser persicus. Aquaculture International 2010; 18:837-841.

https://doi.org/10.1007/s10499-009-9304-0

26. Ohga H, Selvaraj S, Matsuyama M. The roles of kisspeptin system in the reproductive physiology of fish with special reference to chub mackerel studies as main axis. Frontiers in Endocrinology. 2018:9: 147.

https://doi.org/10.3389/fendo.2018.00147

27. Ohga H, Sakanoue R, Ohta K, Matsuyama M. Molecular characterization of kisspeptin 2 dodecapeptide in sixteen species of Scombridae. Fisheries Science. 2020; 86:437-444.

https://doi.org/10.1007/s12562-020-014064

28. Ohga $\mathrm{H}$, Ito $\mathrm{K}$, Matsumori $\mathrm{K}$, Kimura $\mathrm{R}$, Ohta K, Matsuyama M. Leptin stimulates gonadotropin release and ovarian development in marine teleost chub mackerel. General and Comparative Endocrinology, 2020;292:113442. https://doi.org/10.1016/j.ygcen.2020.11344 2

29. Kagawa H, Kasuga, Y., Adachi, J., Nishi, A., Hashimoto, H., Imaizumi, H., Kaji, S. Effects of continuous administration of human chorionic gonadotropin, salmon pituitary extract, and gonadotropinreleasing hormone using osmotic pumps on induction of sexual maturation in male Japanese eel, Anguilla japonica. Aquaculture 2009;296:117-122. https://doi.org/10.1016/j.aquaculture.2009. 07.023

30. Kitahashi T, Alok, D., Ando, H., Kaeriyama, M., Zohar, Y., Ueda, H., Urano, A. GnRH analog stimulates gonadotropin II gene expression in maturing sockeye salmon. Zoological Science. 1998;15(5):761-765.

https://doi.org/10.2108/zsj.15.761

31. Nyuji M, Shiraishi T., Selvaraj, S., Van In, V, Kitano, H., Yamaguchi, A., Okamoto, K., Onoue, S., Shimizu, A., Matsuyama, M. Immunoreactive changes in pituitary FSH and LH cells during seasonal reproductive and spawning cycles of female chub mackerel Scomber japonicus. Fisheries Science 2011;77:731-739.

https://doi.org/10.1007/s12562-011-0380-5

32. Nyuji M, Selvaraj, S., Kitano, H., Shiraishi,

T, Yamaguchi, A.,Shimizu, A., Matsuyama, M. Immunoreactivity of gonadotrophs (FSH and $\mathrm{LH}$ Cells) and gonadotropin subunit gene expression in the male chub mackerel Scomber japonicas pituitary during reproductive cycle. Zoological Science 2012;29(9):623-629.

https://doi.org/10.2108/zsj.29.623

33. Nyuji M., Selvaraj, S., Kitano, H., Ohga, H., Yoneda, M., Shimizu, A., Kaneko, K., Yamaguchi, A., Matsuyama, M. Changes in the expression of pituitary gonadotropin subunits during reproductive cycle of multiple spawning female chub mackerel Scomber japonicus. Fish Physiology and Biochemistry 2012;38:883-897. https://doi.org/10.1007/s10695-011-9576-y

34. Kobayashi T. Molecular mechanisms of gonadal sex differentiation and sex reversal in fish: tilapia and medaka. In Sexual plasticity and gametogenesis in fishes. Nova Science Publishers, Inc.2013; 203-220.

35. Selvaraj S, Kitano H, Amano M, Nyuji M, Kaneko K, Yamaguchi A, Matsuyama, M. Molecular characterization and expression profiles of three $\mathrm{GnRH}$ forms in the brain and pituitary of adult chub mackerel (Scomber japonicus) maintained in captivity. Aquaculture 2012a; 356/357:200210. 
https://doi.org/10.1016/j.aquaculture.2012. 05.015

36. Selvaraj $\mathrm{S}$, Kitano $\mathrm{H}$, Amano M., Ohga $\mathrm{H}$., Yoneda M., Yamaguchi, A., Shimizu, A., Matsuyama, M. Increased expression of kisspeptin and $\mathrm{GnRH}$ forms in the brain of scombroid fish during final ovarian maturation and ovulation. Reproductive Biology and Endocrinology 2012b;10:64. https://doi.org/10.1186/1477-7827-10-64

37. Donaldson EM, Hunter GA. Induced final maturation, ovulation and spermiation in cultured fishes. In: Hoar, W.S., Randall, D.J., Donaldson, E.M. (Eds.), Fish Physiology. Reproduction, IXB, Academic Press, Orlando, FL, 1983; 351-403.

38. Donaldson EM. The integrated development and application of controlled reproduction techniques in Pacific salmonid aquaculture. Fish Physiology and Biochemistry 1986;2:9-24.

https://doi.org/10.1007/BF02264070

39. Lumayno SD, Ohga H, Selvaraj S, Nyuji M, Yamaguchi A, Matsuyama M. Molecular characterization and functional analysis of pituitary $\mathrm{GnRH}$ receptor in a commercial scombroid fish, chub mackerel (Scomber japonicus). General and Comparative Endocrinology 2017;247:143-151. https://doi.org/10.1016/j.ygcen.2017.01.02 7

40. Billard R, Peter RE. Gonadotropin release after implantation of anti-estrogens in the pituitary and hypothalamus of goldfish, Carassius auratus. General and Comparative Endocrinology. 1977;32(2): 213-220.

https://doi.org/10.1016/00166480(77)90154-x

41. Billard R. Testicular feedback on the hypothalamo-pituitary axis in rainbow trout (Salmo gairdnery R.). Annales de biologie animale, biochimie, biophysique. 1978; 18(4):813-818.

https://dx.doi.org/10.1051/rnd:19780509

42. Lam, TJ. Environmental influences on gonadal activity in fish. In: Fish Physiology, Volume 9, Part B (Hoar, W.S., Randall, D.J., Donaldson, E.M., Eds). Elsevier. 1983;65-116.

43. Levavi-Sivan B, Biran, J., Fireman, B. Sex steroids are involved in the regulation of gonadotropin-releasing hormone and dopamine D2 receptors in female tilapia pituitary. Biology of Reproduction.2006; 75:642-650. https://doi.org/10.1095/biolreprod.106.051

540

44. Ohga H., Kaneko, K., Shimizu, A., Kitano, H., Selvaraj, S., Nyuji, M., Adachi, H., Yamaguchi, A., Matsuyama, M. Steroidogenic and maturation-inducing potency of native gonadotropic hormones in female chub mackerel, Scomber japonicus. Reproductive Biology and Endocrinology 2012;10:71.

https://doi.org/10.1186/1477-7827-10-71

45. Bromage, N., Porter, M., \& Randall, C. 2001. The environmental regulation of maturation in farmed finfish with special reference to the role of photoperiod and melatonin. Aquaculture, 2001;197(1):6398.

https://doi.org/10.1016/S0044-

8486(01)00583-X

46. Breton, B., Jalabert, B., Billard, R.,Weil, C. In vitro stimulation of the release of pituitary gonadotropic hormone by a hypothalamic factor in the carp Cyprinus carpio. L. Comptes rendus hebdomadaires des séances de l'Académie des sciences, 1971;273(25): 2591-2594.

https://pubmed.ncbi.nlm.nih.gov/5003756/

47. Breton B, Weil C. Effect of synthetic LH$\mathrm{FSH}$ releasing hormone and hypothalamic extracts of the carp on in vivo gonadotropic hormone secretion in the carp (Cyprinus carpio L.). Comptes rendus hebdomadaires des séances de l'Académie des sciences. 1973;277(19): 2061-2064.

https://pubmed.ncbi.nlm.nih.gov/4208694/

48. Kumarasiri WSAAL, Seneviratne, P. Induced multiple spawnings of Chinese carps in Sri Lanka. Aquaculture. 1988; 74:57-62.

https://doi.org/10.1016/0044-

8486(88)90086-5

49. Halder, S, Sen, S., Bhattacharya, S. Ray, AK., Ghosh, A., Jhingran, A.G. Induced spawning of Indian major carps and maturation of a perch and a catfish by murrel gonadotropin releasing hormone, pimozide and calcium. Aquaculture. 1991; 97(4): 373-382.

https://doi.org/10.1016/0044-

8486(91)90329-6

50. Nandeesha MC, Keshvanath P, Varghese, TJ, Shetty HPC, Gopal Rao K. Alternative inducing agents for carp breeding. In: Progress in Research Carp - Seed Production Technology. Keshvanath, P., Radhakrishnan, K.V. (eds.). 1990; 12-16. 
51. Das SK. Seed production of magur (Clarias batrachus) using a rural model portable hatchery in Assam, India - A farmer proven technology. Aquaculture Asia 2002;7(2) 19-21.

52. Gordin H, Zohar Y. Induced spawning of Sparus aurata (L.) by means of hormonal treatment. Annales de biologie animale, biochimie, biophysique, 1978;18(4):985990.

https://doi.org/10.1051/rnd:19780535

53. Peter RE, Sokolowska M, Nahorniak CS, Rivier JE, Vale WW. Comparison of [D$\mathrm{Arg}^{6}, \mathrm{Trp}^{7}, \mathrm{Leu}^{8}, \mathrm{Pro}^{9}$ NEt]-luteinizing hormone-releasing hormone (sGnRH-A), and [D-Ala ${ }^{6}$, Pro $^{9}$ NEt]-luteinizing hormonereleasing hormone (LHRH-A), in combination with pimozide, in stimulating gonadotropin release and ovulation in the goldfish, Carassius auratus. Canadian Journal of Zoology 1987;65:987-991.

https://doi.org/10.1139/z87-156

54. Peter RE, Lin H-R, Van Der Kraak G, Induced ovulation and spawning of cultured freshwater fish in China: Advances in application of $\mathrm{GnRH}$ analogues and dopamine antagonists. Aquaculture 1988;74:1-10. https://doi.org/10.1016/00448486(88)90080-4

55. Rana KJ. Reproductive biology and the hatchery rearing of tilapia eggs and fry. In: Recent advances in Aquaculture, Muir, J.F., and Roberts, R.J. Eds., 1990;343406.

56. Halder S, Roy $P$, Chatterjee A, Bhattacharya, S. Bioactive forms of gonadotropin releasing hormone in the brain of an Indian major carp, Catla catla (Ham.). J. Biosci. 1995;20:551-561.

57. Gopakumar, G, Rao SG, Nazar, A.K.A., Jayakumar, R., Tamilmani, G., Kalidas, C., Sakthivel, M., Ramesh Kumar, P., Rao, M.V., Hanumantha, Murugan, A., Premjoti, R., Balamurugan, V., Ramkumar, B., Jayasingh, M. Silver Pompano: A potential species for mariculture in India. Fishing Chimes. 2001;31(6):58-60.

58. Podhorec $\mathrm{P}$, Kouril J. Induction of final oocyte maturation in Cyprinidae fish by hypothalamic factors: a review. Veterinary Medicine, 2009;54:97-110. https://doi.org/10.17221/50/2009-VETMED

59. Felix, S., Selvaraj, S., Cheryl Antony, Samuel Moses, T.L.S., Gopalakannan, A. First report on natural spawning of native Asian cichlid fish, pearlspot
(Etroplus suratensis) maintained in FRP tanks in Thiruvallur district, Tamil Nadu, India. International Journal of Fisheries and Aquatic Studies 2017;5(2):23-26.

60. Felix S, Selvaraj S, Cheryl Antony, Samuel Moses, TLS. First report on induced spawning of Indian pearlspot (Etroplus suratensis). Journal of Entomology and Zoology Studies. 2017;5(6):709-713.

61. Raizada, S., Pravin, P., Kumar, A.T., Jena, JK. ICAR Technologies: Breeding and seed production of finfishes and shellfishes. 2019;66

62. Crim LW, Sherwood NM, Wilson CE. Sustained hormone release. Effectiveness of $\mathrm{LHRH}$ analog ( $\mathrm{LHRHa}$ ) administration by either single time injection or cholesterol pellet implantation on plasma gonadotropin levels in a bioassay model fish, the juvenile rainbow trout. Aquaculture. 1988;74(12):87-95.

https://doi.org/10.1016/0044-

8486(88)90089-0

63. Crim LW, Peter RE, Billard R. Stimulation of gonadotropin secretion by intraventricular injection of hypothalamic extracts in the goldfish, Carassius auratus. General and Comparative Endocrinology 1976;30(1):77-82.

https://doi.org/10.1016/0016-

6480(76)90068-X

64. Priyadarshi H, Das, R., Singh, A.A., Patel, A.B., Pandey, P.K. Technology for voluntary captive spawning for Magur. Aqua International 2020;12:50-52.

65. Selvaraj, S., Kitano, H., Fujinaga, Y., Amano, M., Takahashi, A., Shimizu, A., Yoneda, M., Yamaguchi, A., Matsuyama, M. Immunological characterization and distribution of three $\mathrm{GnRH}$ forms in the brain and pituitary gland of chub mackerel (Scomber japonicus). Zoological Science 2009;26 (12): 828-839.

https://doi.org/10.2108/zsj.26.828

66. Sukhan ZP, Kitano, H., Selvaraj, S., Yoneda, M., Yamaguchi, A., Matsuyama, M. Identification and distribution of three gonadotropin-releasing hormone $(\mathrm{GnRH})$ isoforms in the brain of a clupeiform fish, Engraulis japonicus. Zoological Science 2013;30(12):1081-1091.

https://doi.org/10.2108/zsj.30.1081

67. Selvaraj S., Kitano, H., Amano, M., Matsuyama, M. Dynamics of three $\mathrm{GnRH}$ forms in the multiple spawning perciform fish, chub mackerel (Scomber japonicus) and bambooleaf wrasse (Pseudolabrus 
sieboldi). In. Gonadotropin-Releasing Hormone $(\mathrm{GnRH})$ : Production, Structure \& Function. Edited by Prof. Scott Sills. Nova Science Publishers Inc., USA, 2014;29-54.

68. Powell JF., Zohar, Y., Elizur, A., Park, M., Fischer, W. H., Craig, A. G., Rivier, J. E., Lovejoy, DA, Sherwood NM. Three forms of gonadotropin-releasing hormone characterized from brains of one species. Proceedings of the National Academy of Sciences of USA 1994; 91:12081-12085.

https://doi.org/10.1073/pnas.91.25.12081

69. White RB., Fernald RD. Ontogeny of gonadotropin-releasing hormone $(\mathrm{GnRH})$ gene expression reveals a distinct origin for GnRH-containing neurons in the midbrain. General and Comparative Endocrinology. 1998;112:322-329. https://doi.org/10.1006/gcen.1998.7142

70. Okubo K., Amano, M., Yoshiura, Y., Suetake, H., Aida, K. A novel form of gonadotropin-releasing hormone in the medaka, Orvzias latipes. Biochemical and Biophysical Research Communications 2000;276:298-303.

https://doi.org/10.1006/bbrc.2000.3476

71. Okubo K, Mitani H, Naruse K, Kondo M, Shima, A., Tanaka, M., Asakawa, S., Shimizu, N., Yoshiura, Y, Aida, K. Structural characterization of $\mathrm{GnRH}$ loci in the medaka genome. Gene. 2002;293:181189.

https://doi.org/10.1016/s0378-

1119(02)00724-2

72. Suzuki K, Gamble RL, Sower SA. Multiple transcripts encoding lamprey gonadotropin-releasing hormone-I precursors. Journal of Molecular Endocrinology. 2000;24:365-376. https://doi.org/10.1677/jme.0.0240365

73. Kavanaugh SI, Nozaki M, Sower, SA. Origins of gonadotropin-releasing hormone $(\mathrm{GnRH})$ in vertebrates: identification of a novel $\mathrm{GnRH}$ in a basal vertebrate, the sea lamprey. Endocrinology. 2008;149:38603869.

https://doi.org/10.1210/en.2008-0184

74. Gonzalez-Martinez, D., Madigou, T., Zmora, N., Anglade, I., Zanuy, S., Zohar, Y., Elizur, A., Munoz-Cueto, J.A., Kah, O. Differential expression of three different prepro-GnRH (gonadotrophin-releasing hormone) messengers in the brain of the European sea bass (Dicentrarchus labrax). Journal of Comparative Neurology 2001; 429: 144-155. https://doi.org/10.1002/1096-

9861(20000101)429:1\%3C144::aid-

cne11\%3E3.0.co;2-b

75. Zmora N, González-Martínez D, MuñozCueto, JA., Madigou, T., MañanosSanchez. E., Doste, S.Z., Zohar, Y., Kah, O., Elizur, A. The GnRH system in the European sea bass (Dicentrarchus labrax). Journal of Endocrinology 2002; 172:105116. https://doi.org/10.1677/joe.0.1720105

76. Amano $\mathrm{M}$, Oka $\mathrm{Y}$, Yamanome, T., Okuzawa, K., Yamamori, K. Three GnRH systems in the brain and pituitary of a pleuronectiform fish, the barfin flounder Verasper moseri. Cell and Tissue Research. 2002;309:323-329.

https://doi.org/10.1007/s00441-002-0594-z

77. Mohamed JS, Thomas $P$, Khan IA. Isolation, cloning, and expression of three prepro-GnRH mRNAs in Atlantic croaker brain and pituitary. Journal of Comparative Neurology. 2005;488:384-395.

https://doi.org/10.1002/cne.20596

78. Ikemoto, T., Park, M.K. Identification and molecular characterization of three $\mathrm{GnRH}$ ligands and five $\mathrm{GnRH}$ receptors in the spotted green pufferfish. Molecular and Cellular Endocrinology 2005;242(1-2):6779.

https://doi.org/10.1016/j.mce.2005.07.004

79. Kitahashi, T., Sato, H., Sakuma, Y., Parhar, I.S. Cloning and functional analysis of promoters of three $\mathrm{GnRH}$ genes in a cichlid. Biochemical and Biophysical Research Communications 2005;336(2):536-543.

https://doi.org/10.1016/j.bbrc.2005.08.122

80. Mohamed JS., Benninghoff, A.D., Holt, GJ, Khan, I.A. Developmental expression of the $G$ protein-coupled receptor 54 and three $\mathrm{GnRH}$ mRNAs in the teleost fish cobia. Journal of Molecular Endocrinology 2007;38: 235-244.

https://doi.org/10.1677/jme.1.02182

81. Guilgur LG, Ortí G, Strobl-Mazzulla PH, Fernandino JI, Miranda, LA, Somozoa GM. Characterization of the cDNAs encoding three $\mathrm{GnRH}$ forms in the Pejerrey fish Odontesthes bonariensis (Atheriniformes) and the evolution of $\mathrm{GnRH}$ precursors Journal of Molecular Evolution 2007;64: 614-627.

https://doi.org/10.1007/s00239-006-0125-8

82. An KW, Nelson ER, Habibi HR, Choi CY. Molecular characterization and expression of three GnRH forms mRNA during gonad sex-change process, and effect of $\mathrm{GnRHa}$ 
on GTH subunits mRNA in the protandrous black porgy (Acanthopagrus schlegeli). General and Comparative Endocrinology 2008;159: 38-45.

https://doi.org/10.1016/j.ygcen.2008.07.01 2

83. Nocillado JN., Elizur, A. Neuroendocrine regulation of puberty in fish: Insights from the grey mullet (Mugil cephalus) model. Molecular Reproduction and Developement 2008;75:355-61. https://doi.org/10.1002/mrd.20744

84. Hu SY, Chen MH, Lin YC, Lin GH, Gong $\mathrm{HY}$, Yang TH, Wu JL. Cloning and functional analysis of the proximal promoter region of the three $\mathrm{GnRH}$ genes from the silver sea bream (Sparus sarba). Comparative Biochemistry \& Physiology Part B: Biochemical and Molecular Biology 2008;151(4):373-80. https://doi.org/10.1016/j.cbpb.2008.06.015

85. Shahjahan, M., Hamabata, T., Motohashi, E., Doi, H., Ando, H. Differential expression of three types of gonadotropinreleasing hormone genes during the spawning season in grass puffer, Takifugu niphobles. General and Comparative Endocrinology 2010;167:153-163. https://doi.org/10.1016/j.ygcen.2010.01.01 8

86. Nagase T, Kitano, H., Yamaguchi, A., Matsuyama, M. Identification and distribution of three $\mathrm{GnRH}$ forms in bambooleaf wrasse, Pseudolabrus sieboldi. In Program and Abstracts Book of the Japanese Society of Fisheries Science, Spring Meeting, Nagasaki University, 2010;42.

87. Gaillard AL., Tay, B.H., Pérez Sirkin, D.I., Lafont, A.G., De Flori, C., Vissio, P.G., Mazan, S., Dufour, S., Venkatesh, B., Tostivint, $\mathrm{H}$. Characterization of gonadotropin-releasing hormone (GnRH) genes from cartilaginous fish: evolutionary perspectives. Frontiers in Neuroscience 2018;12:607.

https://doi.org/10.3389/fnins.2018.00607

88. Bond, C.T., Francis, R.C., Fernald, R.D., Adelman, J.P. Characterization of complementary DNA encoding the precursor for gonadotropin-releasing hormone and its associated peptide from a teleost fish. Molecular Endocrinology 1991;5(7):931-937.

https://doi.org/10.1210/mend-5-7-931

89. White, S.A., Bond, C.T., Francis, R.C., Kasten, T.L., Fernald, R.D., Adelman, J.P.
A second gene for gonadotropin-releasing hormone: cDNA and expression pattern in the brain. Proceedings of the National Academy of Sciences of USA 1994; 91(4):1423-7. https://doi.org/10.1073/pnas.91.4.1423

90. Lin, X.W., Peter, R.E. Expression of salmon gonadotropin-releasing hormone $(\mathrm{GnRH})$ and chicken $\mathrm{GnRH}-\mathrm{II}$ precursor messenger ribonucleic acids in the brain and ovary of goldfish. General and Comparative Endocrinology 1996;101(3): 282-96.

https://doi.org/10.1006/gcen.1996.0031

91. Klungland $\mathrm{H}$, Lorens JB., Andersen $\mathrm{O}$, Kisen GO, Alestrøm, P. The Atlantic salmon prepro-gonadotropin releasing hormone gene and mRNA. Molecular and Cellular Endocrinology 1992;84(3):167174.

https://doi.org/10.1016/03037207(92)90027-4

92. von Schalburg, KR, Harrower WL, Sherwood NM. Regulation and expression of gonadotropin-releasing hormone in salmon embryo and gonad. Molecular and Cellular Endocrinology 1999;157(1-2):4154.

https://doi.org/10.1016/s03037207(99)00163-x

93. Bogerd, J., Zandbergen, T., Andersson, E., Goos, $H$. Isolation, characterization and expression of cDNAs encoding the catfishtype and chicken-II-type gonadotropinreleasing-hormone precursors in the African catfish. European Journal of Biochemistry 1994;222(2):541-549.

https://doi.org/10.1111/j.1432-

1033.1994.tb18896.x

94. Okubo K, Suetake H, Aida, K. Expression of two gonadotropin-releasing hormone $(\mathrm{GnRH})$ precursor genes in various tissues of the Japanese eel and evolution of GnRH. Zoological Science 1999;16(3):471478.

https://doi.org/10.2108/zsj.16.471

95. Okubo, K, Aida, K. Gonadotropin-releasing hormones (GnRHs) in a primitive teleost, the arowana: phylogenetic evidence that three paralogous lineages of $\mathrm{GnRH}$ occurred prior to the emergence of teleosts. General and Comparative Endocrinology. 2001;124(2):125-133. https://doi.org/10.1006/gcen.2001.7698

96. Torgersen, J., Nourizadeh-Lillabadi, R., Husebye, H., Aleström, P. In silico and in situ characterization of the zebrafish 
(Danio rerio) gnrh3 (sGnRH) gene. BMC Genomics 2002;3(1):25.

https://doi.org/10.1186/1471-2164-3-25

97. Steven, C., Lehnen, N., Kight, K., ljiri, S., Klenke, U., Harris, W.A., Zohar, Y. Molecular characterization of the $\mathrm{GnRH}$ system in zebrafish (Danio rerio): cloning of chicken $\mathrm{GnRH}-\mathrm{II}$, adult brain expression patterns and pituitary content of salmon $\mathrm{GnRH}$ and chicken GnRH-II. General and Comparative Endocrinology 2003;133(1): 27-37.

https://doi.org/10.1016/s00166480(03)00144-8

98. Li, S., Hu, W., Wang, Y. and Zhu, Z. Cloning and expression analysis in mature individuals of two chicken type-II GnRH (cGnRH-II) genes in common carp (Cyprinus carpio). Science China Life Sciences. 2004;47(4):349-358.

99. Li, S.-F., Hu, W., Wang, Y.-P., Sun, Y.-H., Chen, S.-P. and Zhu, Z.-Y. Cloning and expression analysis in mature individuals of salmon gonadotropin-releasing hormone (sGnRH) gene in common carp. Chinese Journal of Genetics. 2004;31(10):10721081.

100. Amano M, Oka $Y$, Kitamura S, Ikuta K, Aida K. Ontogenic development of salmon $\mathrm{GnRH}$ and chicken $\mathrm{GnRH}-\mathrm{Il}$ systems in the brain of masu salmon (Oncorhynchus masou). Cell Tissue Res. 1998;293(3):42734.

101. Gharaei, A., Mahboudi, F., Esmaili-Sari, A., Edalat, R., Adeli, A, Keyvanshokooh, S. 2010. Molecular cloning of cDNA of mammalian and chicken II gonadotropinreleasing hormones (mGnRHs and cGnRH-II) in the beluga (Huso huso) and the disruptive effect of methylmercury on gene expression. Fish Physiology and Biochemistry 2010;36(3):803-817. https://doi.org/10.1007/s10695-009-93560

102. Harvey B, Carolsfeld J. Induced breeding in tropical fish culture. International Development Research Centre, Ottawa, Canada. 1993;144.

103. Mohammadzadeh M, Moradian, F., Yeganeh, S., Falahatkar, B., Milla, S. Design, production and purification of a novel recombinant gonadotropin-releasing hormone associated peptide as a spawning inducing agent for fish. Protein Expression and Purification. 2020;166: 105510.
104. Feng, Z., Xu, B. Inspiration from the mirror: D-amino acid containing peptides in biomedical approaches. BioMolecular concepts, 2016;7:179-187. https://doi.org/10.1515/bmc-2015-0035

105. Maclntosh DJ, Little, DC. Nile tilapia (Oreochromis niloticus) In. Broodstock management and egg and larval quality. Bromage, N.R., Roberts, R.J., Eds., Blackwell Science, Oxford; 1995.

106. Main, K.L., Rhody, N., Nystrom, M., Resleey, M. Species Profile - Florida Pompano. In Southern Regional Aquaculture Centre (SRAC), SRAC Publication No. 2007;7206, 6.

107. Matsuyama, M., Hamada, M., Ashitani, T., Okuzawa, K., Kagawa, H., Tanaka, H., Toshio Iwai, T., Kashiwagi M. Development of LHRH-a copolymer pellet polymerized by ultraviolet and its application for maturation in red seabream Pagrus major during the non-spawning season. Nippon Suisan Gakkaishi 1993; 59(8): 1361-1369. https://doi.org/10.2331/suisan.59.1361

108. Okuzawa, K. Puberty in teleosts. Fish Physiology and Biochemistry. 2002;26:3141. https://doi.org/10.1023/A:1023395025374

109. Weltzien, F.A., Andersson, E., Andersen, Ø., Shalchian-Tabrizi, K., Norberg, B. 2004. The brain-pituitary-gonad axis in male teleosts, with special emphasis on flatfish (Pleuronectiformes). Comparative Biochemistry and Physiology Part A Molecular and Integrative Physiology, 2004;137(3): 447-477.

110. Taranger, G.L., Carrillo, M., Schulz, R.W., Fontaine, P., Zanuy, S., Felip, A., Weltzien, F.A., Dufour, S., Karlsen, O., Norberg, B., Andersson, E., Hansen, T., 2010. Control of puberty in farmed fish. General and Comparative Endocrinology 2010; 165(3):483-515.

https://doi.org/10.1016/j.ygcen.2009.05.00 4

111. Thapa, P, Farber, DL. The role of the thymus in the immune response. Thoracic Surgery Clinics. 2019;29(2):123-131. https://doi.org/10.1016/j.thorsurg.2018.12.0 01

112. Nyuji, M., Kodama, R., Kato, K., Yamamoto, S., Yamaguchi, A., Matsuyama, M. Gonadal development and gonadotropin gene expression during puberty in cultured chub mackerel 
(Scomber japonicus). Zoological Science 2014;31(6): 398-406.

https://doi.org/10.2108/zs130254

113. Ohga, H., Selvaraj, S., Nyuji, M., Kitano, H., Nagano, N., Yamaguchi, A., Matsuyama, M. Functional analysis of kisspeptin peptides in adult immature chub mackerel (Scomber japonicus) using an intracerebroventricular administration method. Neuroscience Letters 2014; 561:203-207.

https://doi.org/10.1016/j.neulet.2013.12.07 2

114. Ohga, H., Matsuyama, M. In vitro action of leptin on gonadotropin secretion in prepubertal male chub mackerel. Comparative Biochemistry and Physiology Part A Molecular and Integrative Physiology, 2021;253:110856.

https://doi.org/10.1016/j.cbpa.2020.110856

115. Ohga, H., Hirata, D., Matsumori, K., Kitano, H., Nagano, N., Yamaguchi, A., Matsuyama, M. Possible role of the leptin system in controlling puberty in the male chub mackerel, Scomber japonicus. Comparative Biochemistry and Physiology Part A Molecular and Integrative Physiology. 2017;203:159-166.

https://doi.org/10.1016/j.cbpa.2016.09.009

116. Hermelink B, Wuertz, S., Trubiroha, A., Rennert, B., Kloas, W., Schulz, C. Influence of temperature on puberty and maturation of pikeperch, Sander lucioperca. General and Comparative Endocrinology 2011;172(2):282-92. doi: 10.1016/j.ygcen.2011.03.013

117. Hermelink, B., Wuertz, S., Rennert, B., Kloas, W., Schulz, C. Temperature control of pikeperch (Sander lucioperca) maturation in recirculating aquaculture systems-induction of puberty and course of gametogenesis, Aquaculture 2013;(400 401): 36-45.

doi:10.1016/j.aquaculture.2013.02.026

118. Melo, MC., Andersson, E., Fjelldal, P.G., Bogerd, J., França, L.R., Taranger, G.L., Schulz, R.W. Salinity and photoperiod modulate pubertal development in Atlantic salmon (Salmo salar). Journal of Endocrinology. 2014;220(3):319-332. doi: 10.1530/JOE-13-0240.

119. Yoshizaki, G., Yazawa, R. Application of surrogate broodstock technology in aquaculture. Fisheries Science. 2019;85: 429-437.

https://doi.org/10.1007/s12562-019-01299y
120. Jin, Y.H., Robledo, D., Hickey, J.M., McGrew, M.J., Houston, R.D. Surrogate broodstock to enhance biotechnology research and applications in aquaculture. Biotechnology Advances. 2021;49:107756.

121. Donaldson, E.M., Hunter, G.A. Sex control in fish with particular reference to salmonids. Canadian Journal of Fisheries and Aquatic Sciences. 1982;39(1):99-110. https://doi.org/10.1139/f82-012

122. Bhandari RK., Alam, M.A., Soyano, K., Nakamura, M. Induction of female-to-male sex change in the honeycomb grouper (Epinephelus merra) by 11ketotestosterone treatments. Zoological Science. 2006;23(1):65-69.

https://doi.org/10.2108/zsj.23.65

123. Alam MA, Bhandari RK, Kobayashi $\mathrm{Y}$, Nakamura, S., Soyano, K., Nakamura, M. 2006. Changes in androgen-producing cell size and circulating 11-ketotestosterone level during female-male sex change of honeycomb grouper Epinephelus merra. Molecular Reproduction and Development 2006;73(2): 206-214.

https://doi.org/10.1002/mrd.20393

124. Alam, M.A., Bhandari, R.K., Kobayashi, Y., Soyano, Y., Nakamura, M. Induction of sex change within two full moons during breeding season and spawning in grouper. Aquaculture 2006;255(1-4):532-535. https://doi.org/10.1016/j.aquaculture.2006. 01.008

125. Bhandari, R.K., Higa, M., Nakamura, S., Nakamura, M. Aromatase inhibitor induces complete sex change in the protogynous honeycomb grouper (Epinephelus merra). Molecular Reproduction and Development, 2004;67(3): 303-307.

https://doi.org/10.1002/mrd.20027

126. Bhandari RK., Komuro, H., Higa, M., Nakamura, M. Sex inversion of sexually immature honeycomb grouper (Epinephelus merra) by aromatase inhibitor. Zoological Science, 2004;21(3): 305-310. https://doi.org/10.2108/zsj.21.305

127. Athauda AR, Saman Bandara. Effect of culture environmental conditions on sex inversion of Asian seabass (barramundi), Lates calcarifer (Bloch). $\mathrm{PhD}$ thesis, James Cook University; 2014. https://researchonline.jcu.edu.au/45404

128. Ravi P, Jiang, J., Liew, WC., Orban, L. Small-scale transcriptomics reveals differences among gonadal stages in Asian 
seabass (Lates calcarifer). Reproducitve Biology and Endocrinology, 2014;12:5. https://dx.doi.org/10.1186\%2F1477-7827$12-5$

129. Hunter GA., Donaldson EM. Hormonal sex control and its application to fish culture. In: W.S. Hoar, W.S., Randall, D.J. and Donaldson E.M. (Eds), Fish Physiology IXB, Academic Press, London. 1983;223303.

130. Kobayashi Y., Nagahama, Y., Nakamura, $M$. Diversity and plasticity of sex determination and differentiation in fishes. Sexual Development. 2013;7:115-125.

131. Kobayashi,Y., Murata, R., Nakamura, M. Physiological and endocrinological mechanisms of sex change in the grouper. In Sexual plasticity and gametogenesis in fishes, Nova Science Publishers, Inc. 2013;221-233.

132. Vera Cruz, E.M., Mair, G.C. Conditions for effective androgen sex reversal in Oreochromis niloticus (L.). Aquaculture 1994;122:237-248.

133. Abucay, JS., Mair, GC. Hormonal sex reversal of tilapias: Implications of hormone treatment application in closed water systems. Aquaculture Research 1997;28:841-845.

https://doi.org/10.1046/j.1365-

2109.1997.00878.x

134. Nakamura, M. Morphological and physiological studies on gonadal sex differentiation in teleost fish. AquaBioScience Monographs 2013;6(1):1-47.

135. Nakamura, M., Nozu, R., ljiri, S., Kobayashi, T, Hirai, T., Yamaguchi, Y., Seale, A., Lerner, D. T., Grau, G.E. 2015. sterilized male Mozambique tilapia, Oreochromis mossambicus. Zoological letters, 2015;1:21.

https://doi.org/10.1186/s40851-015-0021-4
136. Pandian TJ. Genetic sex differentiation in fish. CRC Press, 2012;236.

137. Pandian TJ. Endocrine sex differentiation in fish. CRC Press, 2013;318

138. Arslan T, Phelps RP. Directing gonadal differentiation in bluegill, Lepomis macrochirus (Rafinesque), and black crappie, Pomoxis nigromaculatus (Lesueur), by periodic estradiol- $17 \beta$ immersions. Aquaculture Research 2004; 35: 397-402.

10.1111/j.1365-2109.2004.01029.x

139. Piferrer $F$. Endocrine sex control strategies for the feminization of teleost fish. Aquaculture. 2001;197:229-281.

140. Tseng, MC, Yang DH, Yen TB. Comparative study on hatching rate, survival rate, and feminization of Onychostoma barbatulum (Pellegrin, 1908) at different temperatures and examining sex change by gonad and karyotype analyses. Zoological Studies 2017;56:e16.

doi: 10.6620/ZS.2017.56-16

141. Juan L, Wilfrido, C-S., Arlette, F., Maria, A. Functional feminization of the Mexican snook (Centropomus poeyi) using $17 \beta$ estradiol in the diet. Latin American Journal of Aquatic Research. 2019;47:240250.

142. III RDG. Use of androgens for the production of all male Tilapia aurea (Steindachner). Transactions of the American Fisheries Society 2011; 104(2):342-348.

143. Nivelle R, Gennotte V, Kalala EJK, Ngoc NB, Muller M. Temperature preference of Nile tilapia (Oreochromis niloticus) juveniles induces spontaneous sex reversal. Plos One. 2019;14(3): e0214689. https://doi.org/10.1371/journal.pone.02146 89

(c) 2021 Selvaraj et al.; This is an Open Access article distributed under the terms of the Creative Commons Attribution License (http://creativecommons.org/licenses/by/4.0), which permits unrestricted use, distribution, and reproduction in any medium, provided the original work is properly cited.

Peer-review history:

The peer review history for this paper can be accessed here: https://www.sdiarticle4.com/review-history/75461 